\title{
Increased Production of Amyloid Precursor Protein Provides a Substrate for Caspase-3 in Dying Motoneurons
}

\author{
Natalie Y. Barnes, ${ }^{1}$ Ling Li, ${ }^{1}$ Kazuaki Yoshikawa, ${ }^{2}$ Lawrence M. Schwartz, ${ }^{3}$ \\ Ronald W. Oppenheim, ${ }^{1}$ and Carolanne E. Milligan ${ }^{1}$ \\ ${ }^{1}$ Department of Neurobiology and Anatomy and the Neuroscience Program, Wake Forest University School of Medicine, \\ Winston-Salem, North Carolina 27157, '2Division of Regulation of Macromolecular Functions, Institute for Protein \\ Research, Osaka University, Suita, Osaka 565, Japan, and ${ }^{3}$ Department of Biology, University of Massachusetts, \\ Amherst, Massachusetts 01003
}

\begin{abstract}
Biochemical and molecular mechanisms of neuronal cell death are currently an area of intense research. It is well documented that the lumbar spinal motoneurons of the chick embryo undergo a period of naturally occurring programmed cell death (PCD) requiring new gene expression and activation of caspases. To identify genes that exhibit changed expression levels in dying motoneurons, we used a PCR-based subtractive hybridization protocol to identify messages uniquely expressed in motoneurons deprived of trophic support as compared with their healthy counterparts. We report that one upregulated message in developing motoneurons undergoing cell death is the mRNA for amyloid precursor protein (APP). Increased levels of APP and $\beta$-amyloid protein are also detected within dying motoneurons. The predicted peptide sequence of APP indicates two potential cleavage sites for caspase-3 (CPP-32), a
\end{abstract}

caspase activated in dying motoneurons. When peptide inhibitors of caspase- 3 are administered to motoneurons destined to undergo PCD, decreased levels of APP protein and greatly reduced $\beta$-amyloid production are observed. Furthermore, we show that APP is cleaved by caspase- 3 . Our results suggest that differential gene expression results in increased levels of APP, providing a potential substrate for one of the cell deathactivated caspases that may ultimately cause the demise of the cell. These results, combined with information on the toxic role of APP and its proteolytic by-product $\beta$-amyloid, in the neurodegenerative disease Alzheimer's, suggest that events of developmental PCD may be reactivated in early stages of pathological neurodegeneration.

Key words: apoptosis; Alzheimer's disease; amyloid precursor protein; $\beta$-amyloid; CPP-32; ICE-like proteases
During development, large numbers of cells undergo precise temporal and spatial periods of programmed cell death (PCD). Cell death is currently an area of intense research with the rationale that understanding the process may provide keys to developing therapeutic strategies based on initiating cell death, which would be desirable in cancers, or preventing cell death in neurodegenerative diseases. One region of the avian CNS in which PCD has been extensively characterized is the spinal cord, where $50 \%$ of the developing motoneurons die as they interact with their target (Hamburger, 1958, 1975; Chu-Wang and Oppenheim, 1978a,b; Oppenheim et al., 1978). Spinal motoneurons, like many neuronal populations, depend on adequate supplies of trophic support for their survival when they begin to interact with their target (Hamburger and Oppenheim, 1982; Oppenheim et al., 1988, 1995; Oppenheim, 1991).

Intensive research by many laboratories has suggested that

Received March 27, 1998; revised May 6, 1998; accepted May 12, 1998.

This work is supported by Grant GM40458 from the National Institutes of Health (L.M.S.), by Grants NS20402 and NS31380 from the National Institute of Neurological Disorders and Stroke (NINDS) (R.W.O.), and in part by grants from the North Carolina Biotechnology Center (C.E.M.) and the Spinal Cord Research Foundation (C.E.M.) and by Grant NS36081 from NINDS (C.E.M.). The GenBank sequence accession number for chick APP is AF042098. We thank Steve Robinson for extensive discussions on the initial screen to identify differentially regulated genes, Alan Ladd for technical assistance, and Kristine Novak for advice and discussions on in situ hybridization. We also thank Eric Findeis, Liz Forbes, and Noboro Sato for reading and discussing this manuscript.

Correspondence should be addressed to Dr. C. E. Milligan, Department of Neurobiology and Anatomy, Wake Forest University School of Medicine, Medical Center Boulevard, Winston-Salem, NC 27157.

Copyright (C) 1998 Society for Neuroscience $0270-6474 / 98 / 185869-12 \$ 05.00 / 0$ molecular mechanisms of neuronal death are very complex. Immediate early genes, cell cycle regulators, and Bcl-2-related proteins (including $\mathrm{Bax}, \mathrm{Bcl}-\mathrm{x}$, and $\mathrm{Bad}$ ) have been demonstrated to be positive and negative regulators of neuronal death (Garcia et al., 1992; Boise et al., 1993; Estus et al., 1994; Freeman et al., 1994; Yin et al., 1994; Greenlund et al., 1995; Ham et al., 1995; Mesner et al., 1995; Wang et al., 1995). Most recently, the ced-3/ interleukin-1 $\beta$-converting enzyme (ICE) family of cysteine proteases (caspases) has received intense interest regarding its role in neuronal death (for review, see Schwartz and Milligan, 1996). In fact, we have shown that caspases have a regulatory role in the death of motoneurons deprived of trophic support in vitro, as well as a role mediating the death of motoneurons and interdigital cells in vivo (Milligan et al., 1995; L. Li, D. Prevette, R. W. Oppenheim, and C. E. Milligan, unpublished observations). Despite constitutive expression of several pivotal "cell-death" proteases in all cells (for review, see Schwartz and Milligan, 1996), new gene expression is required for many populations to undergo death. This new gene expression may serve to couple the extracellular signal to the internal execution program or to provide essential caspase substrates that are needed for death to occur.

The difficulty in studying molecular changes in neurons, or any complex tissue displaying PCD in vivo, is that condemned cells are interspersed among viable cells. For our studies, we have characterized and used a motoneuron culture system that mimics many aspects of normal motoneuron cell death and survival in vivo (Milligan et al., 1994). To isolate messages that are differentially regulated during motoneuron death after trophic factor 
deprivation, we used a PCR-based subtractive hybridization protocol. We report that amyloid precursor protein (APP) mRNA expression increases in motoneurons undergoing cell death resulting from trophic factor deprivation. Increased protein levels of APP, and its metabolite $\beta$-amyloid (A $\beta)$, are also differentially detected in dying motoneurons compared with their healthy counterparts. Furthermore, APP also seems to be a substrate of caspase-3, generating intracellular $\mathrm{A} \beta$, that may then promote the demise of the cell. APP and $\mathrm{A} \beta$ may serve roles in naturally occurring programmed cell death that are prominent during development of the CNS, consistent with the hypothesis that these events are reinitiated in some pathological disorders such as Alzheimer's disease.

\section{MATERIALS AND METHODS}

\section{Motoneuron cultures}

Spinal cords from embryonic day 5.0 (E5.0) to E5.5 chicks were dissected in cold PBS, pH 7.4, incubated in trypsin ( $0.25 \%$ in PBS; Life Technologies, Gaithersburg, MD), and the tissue was dissociated by passing it several times through a $1.0 \mathrm{ml}$ pipette tip. The dissociated cell suspension was layered onto a $6.8 \%$ metrizamide (Serva Feinbiochemica, Heidelberg, Germany) cushion and centrifuged at $500 \times g$. The cell layer at the interface, containing primarily motoneurons, was collected. Motoneurons were plated either in 24-well tissue culture dishes (Nunc, Naperville, IL) for collection of RNA or protein $\left(4 \times 10^{4}\right.$ cells/well $)$ or onto glass coverslips (Fisher Scientific, Houston, TX) placed into the wells for immunocytochemistry $\left(1 \times 10^{4}\right.$ cells/coverslip). The wells and coverslips were initially coated with polyornithine $(1 \mu \mathrm{g} / \mathrm{ml}$; Sigma, St. Louis, MO), washed extensively with $\mathrm{dH}_{2} \mathrm{O}$, subsequently coated with laminin $(20$ $\mu \mathrm{g} / \mathrm{ml}$; Life Technologies), and washed extensively with media before the addition of cells. A complete culture medium containing Leibovitz's L15 medium (Life Technologies) supplemented with sodium bicarbonate $(625 \mu \mathrm{g} / \mathrm{ml})$, glucose $(20 \mathrm{mM})$, progesterone $\left(2 \times 10^{-8} \mathrm{M}\right.$; Sigma $)$, sodium selenite $\left(3 \times 10^{-8} \mathrm{M}\right.$; Sigma), conalbumin $(0.1 \mathrm{mg} / \mathrm{ml}$; Sigma $)$, putrescine $\left(10^{-4} \mathrm{M}\right.$; Sigma $)$, insulin $(5 \mathrm{mg} / \mathrm{ml}$; Sigma $)$, and penicillin and streptomycin (Life Technologies) was used. One milliliter of complete medium, with or without muscle extract [MEx; $20 \mu \mathrm{g} / \mathrm{ml}$; prepared as described previously (Oppenheim et al., 1988)], was added to each well. We have shown previously that motoneurons in culture with MEx are healthy and exhibit extensive neurite outgrowth, whereas those without MEx die by 3 d (Milligan et al., 1994). Motoneurons cultured without MEx become committed to undergo apoptosis in $\sim 16 \mathrm{hr}$ by a process that is dependent on de novo gene expression.

\section{Isolation of $R N A$}

RNA was collected from motoneurons cultured either with or without MEx at selected times after initial plating. To collect RNA, we removed culture media from the culture wells and lysed the cells with the UltraSpec RNA isolation system (Biotecx, Houston, TX). To collect RNA from spinal cords, we dissected the lumbar spinal cords of embryonic chicks in cold PBS and homogenized the spinal cords in UltraSpec using a tissue homogenizer. RNA was then isolated according to the manufacturer's instructions. For Northern blots, $10 \mu \mathrm{g}$ of total RNA (determined by absorbance at $260 / 280 \mathrm{~nm}$ ) was loaded into each lane and size fractionated in agarose and formaldehyde gels. Ethidium bromide staining of the gels confirmed that each lane was approximately evenly loaded. RNA was transferred to nitrocellulose (Zetaprobe; Bio-Rad, Hercules, $\mathrm{CA})$ and subsequently probed with ${ }^{32} \mathrm{P}$-labeled cDNA as described below. After washes at high stringency, the membrane was exposed to BioMax x-ray film (Kodak, Rochester, NY)).

To standardize and quantitate possible differences in APP mRNA expression on the Northern blot, we performed densitometry on the ethidium bromide-stained $18 \mathrm{~S}$ RNA and the ${ }^{32}$ P-labeled APP mRNA. The photo of the ethidium bromide-stained gel and the Northern blot film were scanned into the computer using an AGFA Arcus II scanner (Ridgefield Park, NJ) and Adobe Photoshop 4.0 software (San Jose, CA). Kodak Digital Science 1D image analysis software was used to determine the net intensity of the resulting bands. Net intensity represents the sum of the background-subtracted pixel values in the band rectangle. The results are presented as a ratio of APP net intensity to $18 \mathrm{~S}$ net intensity.

\section{PCR-based subtractive hybridization}

Total RNA was collected from motoneurons in culture with ("healthy") and without ("dying") MEx at the time when $\sim 50 \%$ of the cells deprived of muscle extract are committed to die [15-20 hr after initial plating (Milligan et al., 1994)]. From one culture, $\sim 10 \mu \mathrm{g}$ of total RNA was collected for each condition $( \pm \mathrm{MEx})$. A major problem with any librarybased screening protocol involving the use of motoneurons is the limited quantity of starting RNA. From one culture condition $( \pm \mathrm{MEx}), \sim 100 \mathrm{ng}$ of poly $\left(\mathrm{A}^{+}\right)$mRNA can be collected, but most cDNA library techniques require up to $10 \mu \mathrm{g}$ of mRNA as starting material, $\sim 1000$-fold more than in a single culture dish. Accordingly, RNA from several cultures was pooled, and an initial amplification of the mRNA obtained from the motoneuron cultures was performed using the MEGAscript T7 Kit (Ambion, Austin, TX). The RNA was then converted to cDNA and used in a PCR-based subtractive hybridization protocol to isolate upregulated messages (Wang and Brown, 1991). The specifics of this technique have been described in detail previously (see Schwartz et al., 1995). In brief, the protocol involves digestion of cDNA with blunt end, four-basecutting restriction enzymes [it is necessary to determine the best restriction enzymes for each species to obtain fragments of 150-500 base pairs (bp) in size; for our purposes, we use Alu and HaeIII]; ligation of linkers to the digested cDNA to allow PCR amplification; PCR amplification; biotinylation of the driver cDNA (e.g., cDNA from healthy cells); a series of long and short hybridizations of biotinylated driver cDNA with unlabeled tracer cDNA (e.g., cDNA from dying cells); removal of common sequences; further PCR amplifications, followed by biotinylation of the driver cDNA; a series of long and short hybridizations to allow for removal of common sequences (these steps allow rarer, less abundant transcripts to be identified); and cloning of subtracted cDNA into pBluescript KS (Stratagene, La Jolla, CA).

\section{Embryonic chick lumbar spinal cord cDNA library generation and screening}

A cDNA library from E7 and E8 chick lumbar spinal cord was constructed in the ZAP Express Vector according to the manufacturer's protocols (Stratagene) to generate a directional library. Accordingly, all of the recommended controls were performed to insure that each step was completed successfully. The resulting library was amplified one time and has an average insert size of 1.05 kilobase pair $(\mathrm{kbp})$ and a titer of $10^{10} \mathrm{pfu} / \mathrm{ml}$. To screen the library for the full-length recombinants, we isolated the insert of clone 22 and radiolabeled the insert for use as a hybridization probe. Approximately $10^{6}$ plaques were screened. Positive clones were subjected to secondary and tertiary screening before sequence analysis. Positive clone 22-2a was excised and sequenced using the Taq Dye Deoxy Terminator Cycle Sequencing Kit (Applied Biosystems, Foster City, CA) at the Wake Forest University School of Medicine Sequencing Facility on model 377 DNA sequencer (Applied Biosystems). The insert from clone 22-2a was isolated, radiolabeled, and used to probe a chicken brain 5 '-STRETCH cDNA library from Clontech (Cambridge, UK). Again, $\sim 1 \times 10^{6}$ plaques were screened initially, and positive clones were subjected to secondary screening. DNA was isolated from the lambda lysate of clone 8.2 and purified using the Qiagen (Hilden, Germany) Lambda Mini Kit. The insert was subcloned into pBluescript (Stratagene) and sequenced. Sequence analysis on both clones was performed using the Wisconsin Genetics Computer Group software package version 8.1 and MacVector 6.0 (Oxford Molecular Group, Oxford, UK).

\section{In situ hybridization}

Clone 22-2a was digested with SpeI to obtain a $1.7 \mathrm{kbp}$ fragment that was cloned into pBluescript (Stratagene). This fragment contained all of the APP open-reading frame present in clone 22-2a. Digoxigenin-labeled riboprobes (antisense and sense) were prepared according to the manufacturer's protocol (Boehringer Mannheim, Indianapolis, IN).

In situ hybridization protocol. The in situ hybridization protocol used is similar to previously described methods (Yamamoto et al., 1997). Briefly, E5, E8, and E13 chick embryos (at least three for each age) were fixed in $4 \%$ paraformaldehyde and cryoprotected in $10 \%$ and then $20 \%$ sucrose. Sections were cut $(12 \mu \mathrm{m})$ and stored at $-80^{\circ} \mathrm{C}$. Slides were baked overnight at $40^{\circ} \mathrm{C}$ before being incubated with hybridization buffer containing a 1:1000 dilution of either sense or antisense riboprobe at $60^{\circ} \mathrm{C}$ overnight. The next day, slides were washed at $65^{\circ} \mathrm{C}$ and incubated in a blocking reagent (Boehringer Mannheim) at room temperature. Slides were then incubated with a 1:1000 dilution of anti-digoxigenin-AP con- 
jugate (Boehringer Mannheim) at room temperature and then washed. Slides were incubated overnight at room temperature with a color solution containing nitroblue tetrazolium and 5-bromo-4-chloro-3-indolyl phosphate (Boehringer Mannheim). After this, the slides were washed with PBS, stained with the bis-benzimidazole dye Hoechst 33342 (10 $\mu \mathrm{g} / \mathrm{ml}$ in PBS; Sigma) to allow visualization of nuclei, and coverslipped with Gel/Mount (Biomeda, Foster City, CA).

Cell counts. In every 10th section through the E8 lumbar spinal cord, the nuclei were visualized using the narrow-band UV filter cube on an Olympus BX60 Fluorescence DIC Research Microscope (Tokyo, Japan). Healthy and pyknotic nuclei were identified based on criteria previously described (Chu-Wang and Oppenheim, 1978a,b; Clarke and Oppenheim, $1995)$ and were counted. Examples of healthy and pyknotic motoneuron nuclei are shown (see the inset of Fig. $3 E$ ). Low level illumination allowed for the visualization of the cell body to determine whether it was immunopositive for APP message. The percent of healthy cells versus the percent of pyknotic cells expressing APP message was compared. The nonparametric Mann-Whitney $U$ test was performed to determine statistically significant differences.

\section{Western blot analysis}

In some experiments, motoneuron cultures were treated with the CPP-32 inhibitor DEVD-aldehyde (DEVD-CHO; $10 \mu \mathrm{g} / \mathrm{ml}$; Bachem, King of Prussia, PA). The peptide inhibitor was added every $2 \mathrm{hr}$ between 14 and $24 \mathrm{hr}$. Protein samples were collected in Laemli buffer and then loaded $(10 \mu \mathrm{g}$ ) onto an $8 \%$ (for APP) or $15 \%$ (for A $\beta$ ) PAGE gel. The protein concentration of the samples was initially determined by the Bradford assay (Bradford, 1977; Ausubel et al., 1996). Electrophoresis samples were transferred to Immobilon-P membrane (Millipore, Bedford, MA), stained with Ponceau S solution to confirm transfer and uniform loading of gels, and then washed with PBS $+0.05 \%$ Tween 20 (PBST). Membranes were blocked with PBST $+5 \%$ nonfat dry milk, followed by overnight incubation with a polyclonal antibody to APP (1:200; Serotec, Oxford, UK) or A $\beta$ (1:200; Serotec). After extensive washes in PBST, an HRP-conjugated anti-rabbit secondary antibody was applied (1:2500; Jackson ImmunoResearch, West Grove, PA), and the ECL kit (Amersham, Arlington Heights, IL) was used to detect the reaction product. A total of eight Western blots, representing eight independent motoneuron cultures, was used (four blots for each antibody).

Densitometry was performed on the Western blots using the methods described above for the Northern blot. To make comparisons between the four Western blots, net intensity values for each blot were normalized to the control situation (protein extract collected from healthy cells supplied with MEx) of that blot so that the results are expressed as percent control. The nonparametric Mann-Whitney $U$ test was performed to determine statistically significant differences between experimental and control conditions.

\section{Immunocytochemistry}

Motoneurons were cultured on glass coverslips as described above. At appropriate times, the coverslips were removed from the tissue culture wells and placed for 3-5 min into wells containing $10 \%$ formaldehyde in PBS. After fixation, the coverslips were transferred into wells containing PBS. APP or A $\beta$ was detected using the polyclonal antibodies described above (1:200 in PBS $+0.3 \%$ Triton X-100 + 4\% nonfat dry milk). After overnight incubation with the primary antibody and several washes in PBS, a rhodamine-conjugated secondary antibody was applied (1:50 in PBS $+0.3 \%$ Triton X-100 + 4\% nonfat dry milk; Jackson ImmunoResearch). Coverslips were then washed with PBS and stained with the bis-benzimidazole dye Hoechst $33342(10 \mu \mathrm{g} / \mathrm{ml}$ in PBS; Sigma) to allow visualization of nuclei. Control reactions omitting the primary antibodies resulted in no labeling with the secondary antibodies (data not shown). Preimmune serum from a rabbit used to generate polyclonal antibodies for independent work was used in place of the primary antibody as an additional control. Again, no specific labeling was observed.

Surviving and APP- or A $\beta$-immunopositive motoneurons were counted in $24 \mathrm{hr}$ cultures either supplied with (healthy) or deprived of (dying) MEx. This time point was chosen because although cells deprived of MEx have become committed to cell death, there are few cells that exhibit overt signs of apoptosis and at later times the number of surviving cells is greatly reduced in these cultures (Milligan et al., 1994). For a cell to be counted as "surviving," its cell body must be present in the field of view, and it must possess a uniform, noncondensed nucleus as detected by Hoechst 33342 staining when viewed using the narrow-band UV filter cube on an Olympus BX60 Fluorescence DIC Research Mi- croscope. APP- or A $\beta$-immunoreactivity in surviving cells (see Figs. $4 A$, $5 A$, respectively) was detected by switching the UV filter cube with a rhodamine filter cube. For all experiments, surviving cells were counted in five predetermined $40 \times$ objective fields for each coverslip. In each condition $( \pm \mathrm{MEx}), 20-30$ cells were counted in each field. The percent of APP-immunoreactive surviving cells was calculated, and the nonparametric Mann-Whitney $U$ test was used to determine statistically significant differences between healthy cultures supplied with MEx and dying cultures that were deprived of MEx.

\section{Assay for cleavage of APP by caspase-3}

The full-length human $\mathrm{APP}_{695}$ was cloned into pBluescript $\mathrm{KS}$ and in vitro translated using the TNT T7-Coupled Reticulocyte Lysate System (Promega, Madison, WI) that incorporates $\left[{ }^{35} \mathrm{~S}\right]$ methionine (Amersham) into the protein. Purified caspase-3, reaction buffer, and AcDEVD-CHO were obtained as part of the Caspase-3 QuantiZyme Assay System (Biomol, Plymouth Meeting, PA). To determine whether caspase- 3 cleaves APP, we added $5 \mu$ l of the TNT reaction product to reaction buffer (50 mM HEPES, pH 7.4, $100 \mathrm{~mm} \mathrm{NaCl}, 0.1 \%$ 3-[(3cholamidopropyl)dimethylammonio]-1-propanesulfonate, $10 \mathrm{~mm}$ DTT, 1 mM EDTA, and 10\% glycerol) and $100 \mathrm{U}$ of caspase- 3 (human, recombinant) and incubated for $1 \mathrm{hr}$ at $37^{\circ} \mathrm{C}$ with or without $5 \mu \mathrm{M}$ DEVDCHO. At the end of the incubation, $20 \mu \mathrm{l}$ of SDS loading buffer was added to each sample, and the samples were boiled and fractionated on a $15 \%$ SDS-PAGE system. The gels were then stained with Coomassie blue, destained and incubated in Amplify (Amersham), and dried and subjected to film autoradiography (BioMax x-ray film; Kodak).

\section{RESULTS}

\section{A PCR-based subtractive hybridization scheme was used to isolate differentially expressed messages in dying motoneurons}

To isolate differentially expressed genes during motoneuron death, we used a PCR-based subtractive hybridization protocol. This approach was based on the likelihood that during programmed cell death, a limited number of genes are differentially transcribed (Schwartz et al., 1990). We have used the PCR-based subtractive hybridization protocol that was originally used to identify numerous genes involved in developmental events of tail resorption and limb formation of the tadpole (Buckbinder and Brown, 1992; Wang and Brown, 1991). In our screen, 40 potentially upregulated clones were initially identified. The sizes of these clones ranged between 50 and $200 \mathrm{bp}$. This small size allowed for rapid sequence analysis to determine the identity of the clones. Initial sequence analysis of clone 22 indicated that it was of potential interest. Clone 22 was confirmed to have increased expression in motoneurons deprived of muscle extract (i.e., those that will die) as compared with healthy motoneurons supplied with trophic support (data not shown).

\section{A cDNA library was screened to isolate the full-length recombinant encoding clone 22}

To obtain the full-length recombinant encoding clone 22, an embryonic chick spinal cord cDNA library was screened using clone 22 as a probe. A single positive recombinant, 22-2a, was isolated, excised, and sequenced. The insert of this recombinant is 2123 bp long and contains 1395 bp of the $3^{\prime}$-end of an openreading frame (orf). The predicted protein product of this orf has $95 \%$ identity with human $\mathrm{APP}_{695}$ (Fig. 1) and thus was designated chick APP. A second chick brain 5'-STRETCH cDNA library (Clontech) was screened using clone $22-2 \mathrm{a}$ as a probe to obtain the $5^{\prime}$-end of chick APP. Positive clone 8.2 was isolated, and its insert was cloned into pBluescript (Stratagene). This clone was $2219 \mathrm{bp}$ long and extended the chick APP sequence $221 \mathrm{bp}$ in the 5 ' direction. Sequence analysis revealed the presence of two potential caspase cleavage sites in the APP protein, one located 




Figure 1. Amino acid sequence alignment of chick APP and human $\mathrm{APP}_{695}$ (accession number Y00264) indicates that the two proteins are $95 \%$ identical. Sequence of the 2123 bp clone 22-2a revealed a 1395 bp open-reading frame. Sequence from clone 8.2 added $221 \mathrm{bp}$ to the $5^{\prime}$-end. The vertical lines indicate identical amino acids; the dots indicate similar amino acids. The two putative caspase cleavage sites are in bold. The $\mathrm{A} \beta 40$ peptide is boxed. The arrow indicates the site where additional exons are inserted in the $\mathrm{APP}_{751}$ and $\mathrm{APP}_{770}$ isoforms.

upstream (DEVD) and one located downstream (EVD) of the A $\beta$ region (Fig. 1).

\section{Chick APP mRNA is induced in motoneurons deprived of trophic support}

Total RNA was collected from motoneurons grown in culture with or without MEx, a potent source of trophic support, and was used to generate a Northern blot that was probed with clone 22-2a under high stringency conditions. A $2.3 \mathrm{kbp}$ message was detected, in agreement with the reported size for human $\mathrm{APP}_{695}$ (Fig. 2). Although there also appears to be some expression of $\mathrm{APP}_{695}$ in healthy motoneurons supplied with MEx, the message appears to be increased in the cells cultured without MEx (dying cells) as compared with cells cultured with MEx (healthy cells). The net intensity of the APP message was normalized to $18 \mathrm{~S}$ RNA and compared between cells supplied with MEx versus those deprived. This analysis indicated a twofold increase in dying versus healthy cells (ratio of net intensity APP:18 S, 0.24 for $+\mathrm{MEx}$ and 0.45 for $-\mathrm{MEx})$.

\section{In situ hybridization of APP demonstrates that it is developmentally regulated in the embryonic chick spinal cord}

In situ hybridization using a $1.5 \mathrm{kbp}$ antisense riboprobe against the coding region of chick APP was performed on tissue sections from E5, E8, and E13 chick lumbar spinal cords. These time points were chosen to represent periods before, during, and after naturally occurring lumbar motoneuron cell death, respectively (Hamburger, 1958, 1975). At E5, expression of APP is localized to the ventral lateral regions of the spinal cord, especially in the

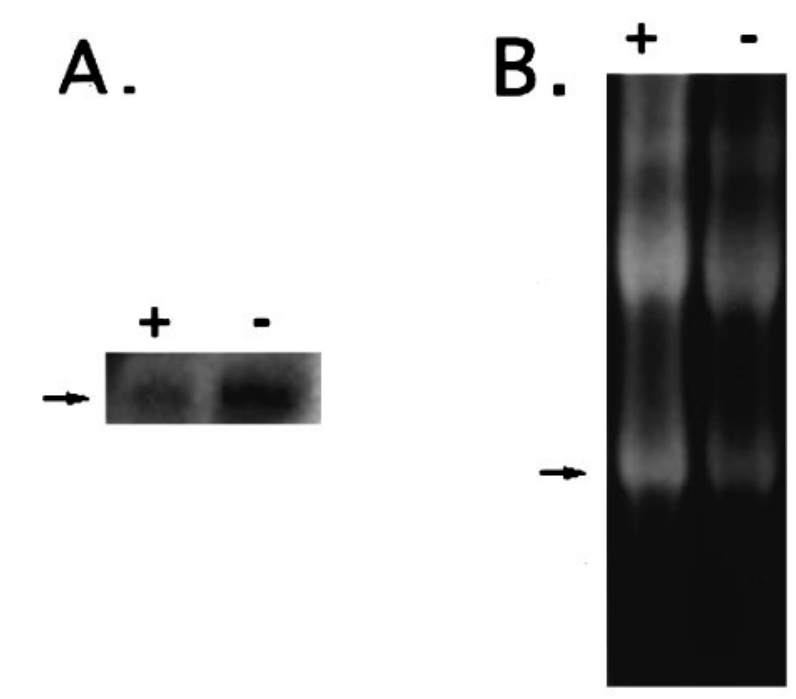

Figure 2. The message for chick APP shows increased expression in motoneurons deprived of MEx in vitro. RNA was collected from motoneurons with $(+)$ or without $(-)$ MEx after $24 \mathrm{hr}$ in culture. $A$, The Northern blot was probed with ${ }^{32} \mathrm{P}$-labeled clone $22-2 \mathrm{a}$ (chick APP) under high stringency conditions, and the $2.3 \mathrm{kbp}$ message was detected (arrow). $B$, The ethidium bromide-stained RNA gel before transfer to membrane with the $18 \mathrm{~S}$ RNA is indicated (arrow).

lateral motor column (Fig. $3 A$ ). Intense localization of the message was also observed in the roof plate and developing dermatomes. Little or no message was detected in the ventricular zone of the spinal cord or in other regions of the embryo that were included in the tissue section. By E8, the expression of APP increased and appeared to be rather ubiquitous in most neurons of the thoracic, lumbar, and sacral spinal cord, although the lumbar spinal motoneurons appeared to have the most intense signal (Fig. 3B). With the exception of the developing muscle (data not shown), no other non-neuronal regions demonstrated detectable APP message. By E13, the level of message in the spinal cord appeared to be decreased, although detectable levels were maintained in the lumbar cord (Fig. 3C). Interestingly, by E13, there was little to no detectable APP in regions of the spinal cord rostral or caudal to the lumbar region. Furthermore, nonneuronal tissues did not show any detectable levels of APP. The "sense" control riboprobe did not display any hybridization signal (Fig. $3 F$ ).

Because intense levels of APP were detected in the lumbar spinal motoneurons on E8, the time of maximum naturally occurring cell death, sections were counterstained with the DNAbinding dye bis-benzimidazole Hoechst 33342 to allow visualization of nuclei. Dying and healthy motoneurons were identified by criteria previously described (Clarke and Oppenheim, 1995). Although many motoneurons expressed APP mRNA, all of the observed pyknotic nuclei in the lateral motor column were intensely labeled for APP message (Fig. 3D,E). To determine the significance of this observation, we counted normal or healthy motoneurons in the lateral lumbar motor column that express APP message and compared these counts with that of pyknotic motoneurons that also expressed the message; $64.33 \pm 3.24 \%$ of the healthy motoneurons expressed the APP message compared with $92.76 \pm 3.45 \%$ of the pyknotic motoneurons (mean \pm SEM; $n=3$ E8 animals). These differences were determined to be statistically significant $(p \leq 0.0001)$. Furthermore, this double staining confirmed that APP was localized primarily within neu- 

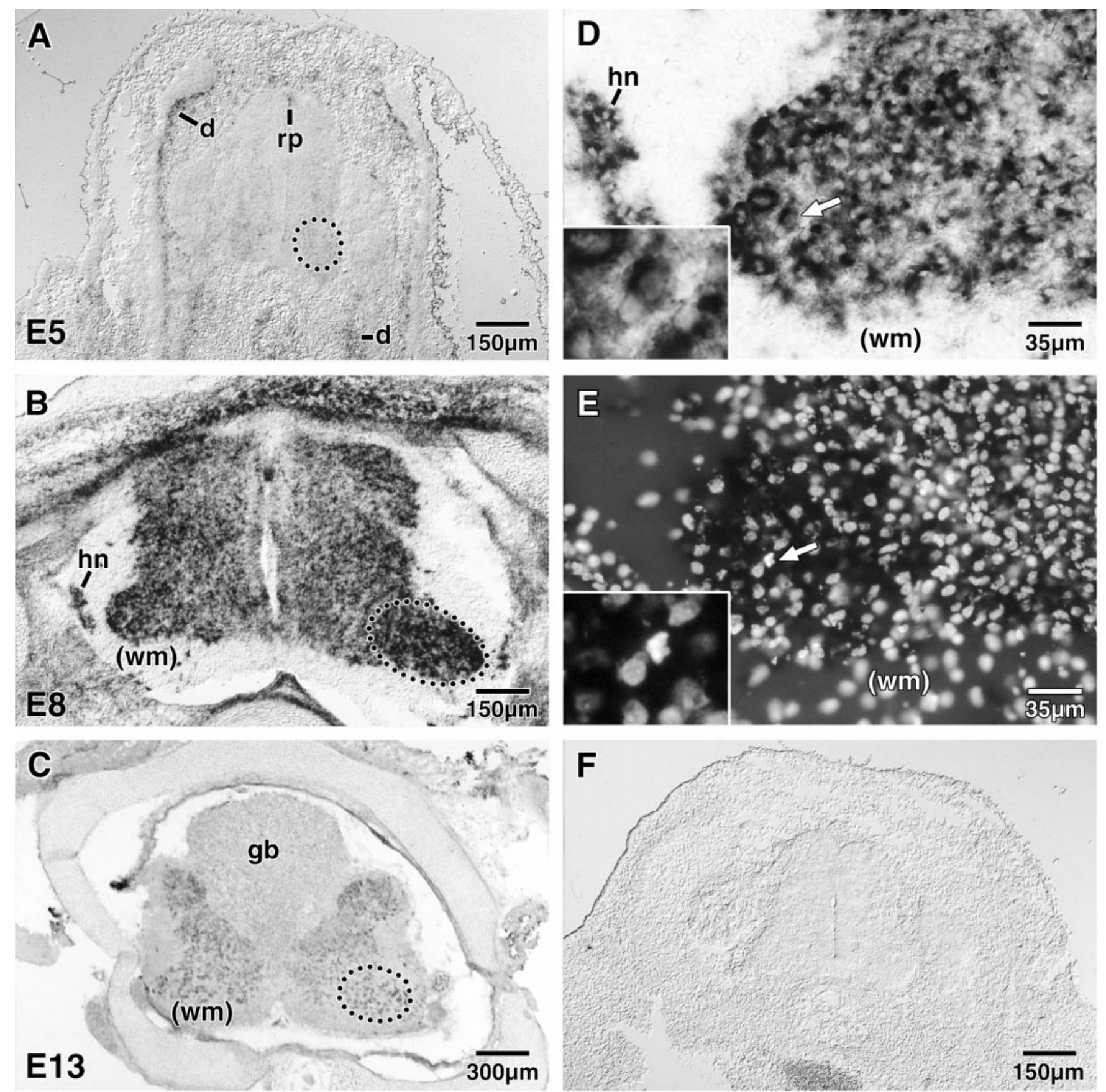

Figure 3. In situ hybridization of APP in the developing spinal cord. $A-C$, APP mRNA expression in the lumbar spinal cord was examined before ( $A$; E5), during ( $B$; E8), and after $(C$; E13) the period of naturally occurring lumbar motoneuron cell death. At E5, a weak signal was detected in the ventrolateral region of the spinal cord including the lateral motor column (outlined circle in $A$ ). A more intense signal was also detected in the roof plate of the spinal cord and the developing dermatomes. At E8, a very intense signal was detected in most neuronal cell types, with the strongest signal appearing in the lateral motor column (outlined oval in $B$ ). At E13, the intensity of the APP signal decreased compared with that at E8 but was still detectable. At this time the signal in the lateral motor column (outlined oval in $C$ ) was similar to that of other regions of the lumbar spinal cord. $D$, $E$, High power photomicrographs of the E8 left lateral motor column $(B)$ are shown in $D$ (APP message) and $E$ (DNA-binding bis-benzimidazole dye Hoechst 33342). $D$ and $E$ and the insets in each are of the same field. Although many of the motoneurons in the lateral motor column exhibited a strong signal $(64.33 \pm 3.24 \%)$, pyknotic motoneurons almost always displayed a strong signal for APP $(92.76 \pm 3.45 \%$; arrow in $D, E)$. The insets in $D$ and $E$ show the region of the arrow enlarged to illustrate that the indicated cell exhibits the characteristic apoptosis (condensed, lobular nuclei) as compared with that of the adjacent cell that exhibits a noncondensed, intact nuclei. The APP message appears to be specific for neuronal phenotypes, because glial cells in the white matter do not show any label. $F$, The negative control (sense strand) displayed no staining. Representative photomicrographs are shown. At least three animals/age were examined; APP expression was consistent between animals of the same age. $d$, Dermatomes; $g b$, glycogen body; $h n$, Hofmann's nucleus; $r p$, roof plate; $w m$, white matter. Note that the cross-section shown in $B$ is from a normal E8 lumbar spinal cord that was cut somewhat obliquely; this explains why the lateral motor column on the left is smaller than the one on the right. 
ronal cells, because many presumptive glial cells, especially those within the white matter, displayed no detectable message.

\section{Immunocytochemistry revealed that APP and $A \beta$ have a unique distribution in motoneurons deprived of trophic support compared with that in healthy motoneurons supplied with trophic support}

Initially after plating, motoneurons in culture either with or without trophic support showed weak, uniform distribution of APP immunoreactivity that was observed in both the cell body and newly formed neurites (data not shown). In both treatment groups, cells at this stage appeared to be healthy, as demonstrated by uniform nuclear staining with Hoechst stain. In motoneurons deprived of MEx, the APP immunoreactivity appeared to change as these cells became committed to and subsequently underwent cell death. We have shown previously that motoneurons deprived of MEx become committed to undergo cell death 16-18 hr after plating in vitro, and by $3 \mathrm{~d}$ these cells have died (Milligan et al., 1994). By $20 \mathrm{hr}$, APP immunoreactivity appears to increase in motoneurons deprived of MEx (Fig. 4A). Interestingly, there seem to be focal regions or aggregations of APP immunoreactivity in these cells. These aggregations appeared in two specific locations, at the distal region of the primary neurite or, more frequently, within the cell body between the nucleus and the proximal region of the primary neurite (Fig. $4 A$ vs $E$ ). By $36 \mathrm{hr}$, cultures deprived of MEx contained numerous cells that exhibited condensed nuclei, a hallmark of apoptosis (Fig. 4D). In most, if not all cases, cells in culture with apoptotic nuclei also exhibited intense APP immunoreactivity (Fig. $4 C, D$ ). These patterns of APP immunoreactivity were rarely observed in motoneurons provided with MEx (Fig. 4E). In fact, after $24 \mathrm{hr}$ in culture, $16.17 \pm 3.99 \%$ of motoneurons supplied with MEx expressed APP immunoreactivity as described above, compared with $67.10 \pm 3.28 \%$ of the cells in cultures deprived of MEx (mean \pm SEM; $n=3$ experiments with 2 coverslips/condition/experiment). These differences were determined to be statistically significant $(p=0.0022)$.

Before MEx-deprived motoneurons in vitro become committed to cell death, immunoreactivity for $\mathrm{A} \beta$ appeared uniform within the cells. However, motoneurons deprived of MEx and committed to undergo cell death (by $24 \mathrm{hr}$ ) displayed diffuse $\mathrm{A} \beta$ immunoreactivity that appeared to be confined to the cell body and proximal regions of the neurites (Fig. 5A). Cells supplied with MEx showed a more uniform staining pattern that was somewhat less intense (Fig. 5E). Because all cells in culture for $24 \mathrm{hr}$ either with or without MEx expressed $\mathrm{A} \beta$ immunoreactivity, it was impossible to quantitate potential differences between the two ( $100 \%$ vs $100 \% ; n=3$ experiments with 2 coverslips/condition/ experiment). The differences in apparent intensity of $\mathrm{A} \beta$ immunoreactivity, however, may account for the twofold increased levels of $\mathrm{A} \beta$ in cells deprived as compared with those supplied with MEx observed on the Western blots described below. By 36 $\mathrm{hr}$ in culture without trophic support, motoneurons with $\mathrm{A} \beta$ immunoreactivity, although not necessarily more numerous compared with healthy cultures, were somewhat more intense, and cells exhibiting apoptotic nuclei almost always showed intense $\mathrm{A} \beta$ immunoreactivity. As noted above, cells denied MEx did appear to have somewhat more intense immunoreactivity compared with cells with MEx, but such differences cannot be reliably quantitated. However, one striking difference between MEx-deprived versus control cultures was the presence of $\mathrm{A} \beta$ immunoreactivity localized in areas that contained only cellular debris (Fig. 5C,D).
To quantitate this phenomena, we counted immunoreactive-A $\beta$ "spots" using the methods described for the cell counts. There were statistically significant increases in the numbers of $\mathrm{A} \beta$ immunoreactive spots in cultures deprived of MEx $(42.33 \pm 5.84)$ versus healthy cultures $(7.17 \pm 2.73 ; p=0.0022$; mean $\pm \mathrm{SEM}$; $n=3$ experiments with 2 coverslips/condition/experiment). Although the number of these spots presumably reflect the increased cell death that occurs in cultures deprived of MEx, similar patterns of immunoreactivity were not observed in cultures stained with other antibodies.

Attempts to determine the cellular localization of APP and A $\beta$ in the developing spinal cord using these antibodies were unsuccessful. To perform immunocytochemistry to detect these molecules, we were required to pretreat the tissue with formic acid for antigen recovery. In our hands, given the delicate nature of embryonic CNS tissue, this treatment damaged the tissue such that reliable and consistent APP or A $\beta$ immunocytochemistry of the cellular or subcellular level was not possible.

\section{Amyloid precursor protein seems to be a substrate for caspase-3 (CPP-32), which results in the production of a $\beta$-amyloid cleavage product}

The predicted peptide sequence of chick APP, as with human APP, indicated two potential cleavage sites for caspase-3 (CPP32), a cysteine protease known to be active in the cell death of many cell types, including motoneurons ( $\mathrm{Li}$ et al., 1996; Li, Prevette, Oppenheim, and Milligan, unpublished observations). To examine whether the increased production of APP provides a substrate for caspase-3, we treated cultured motoneurons with the caspase-3 peptide inhibitor DEVD-CHO during the period of cell death (treatment with DEVD-CHO prevents motoneuron cell death after trophic factor deprivation) (Li et al., 1996; Li, Prevette, Oppenheim, and Milligan, unpublished observations), and protein extracts were subsequently collected. Western blot analysis demonstrated a threefold increased production of APP and a twofold increase in $\mathrm{A} \beta$ in motoneurons deprived of $\mathrm{MEx}$ compared with those with MEx (Fig. 6). In cells deprived of MEx, but also treated with DEVD-CHO, APP appeared to be decreased to levels similar to those observed for cells supplied with MEx (Fig. 6A). The levels of $\mathrm{A} \beta$ were greatly reduced in extracts collected from DEVD-treated cells deprived of MEx versus nontreated MEx-deprived cells. Furthermore, the levels of $\mathrm{A} \beta$ observed in DEVD-treated cells were significantly lower than that observed in healthy cells (Fig. 6B). This effect seems to be specific for caspase-3, because treatment with the caspase-1 (ICE) inhibitor YVAD was not effective in preventing the production of $\mathrm{A} \beta$ (data not shown). Interestingly, the $\mathrm{A} \beta$ band observed was $\sim 16 \mathrm{kDa}$. This size approximately corresponds to the predicted size $(19 \mathrm{kDa})$ of the fragment that would be generated if APP were proteolytically processed at the caspase- 3 cleavage sites.

\section{Caspase-3 cleaves APP}

To determine directly whether APP serves as a substrate for caspase-3, we in vitro transcribed/translated the full-length human $\mathrm{APP}_{695}$ in the presence of $\left[{ }^{35} \mathrm{~S}\right]$ methionine to produce radioactive protein. When this APP was incubated with purified, recombinant, human caspase-3, cleavage of APP was observed (Fig. 7). The sizes of the cleaved products suggest that caspase-3 cleaves APP at both predicted cleavage sites (Fig. 1). Multiple bands were present in the in vitro transcribed/translated reaction product. These bands are thought to be the result of false start sites (all of which will include the downstream caspase-3 cleavage 


\section{APP Immunoreactivity}
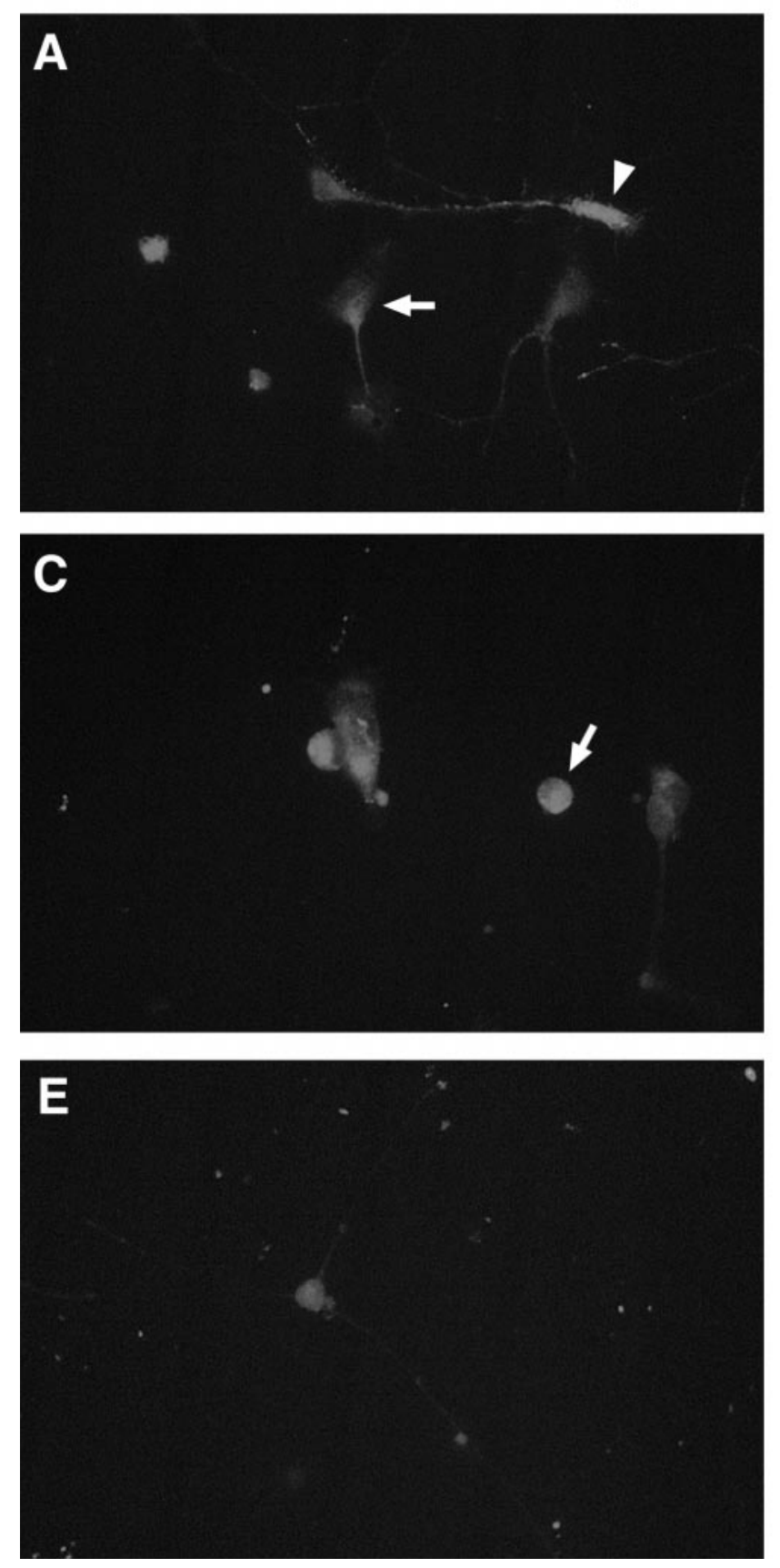

\section{Hoechst Stain}
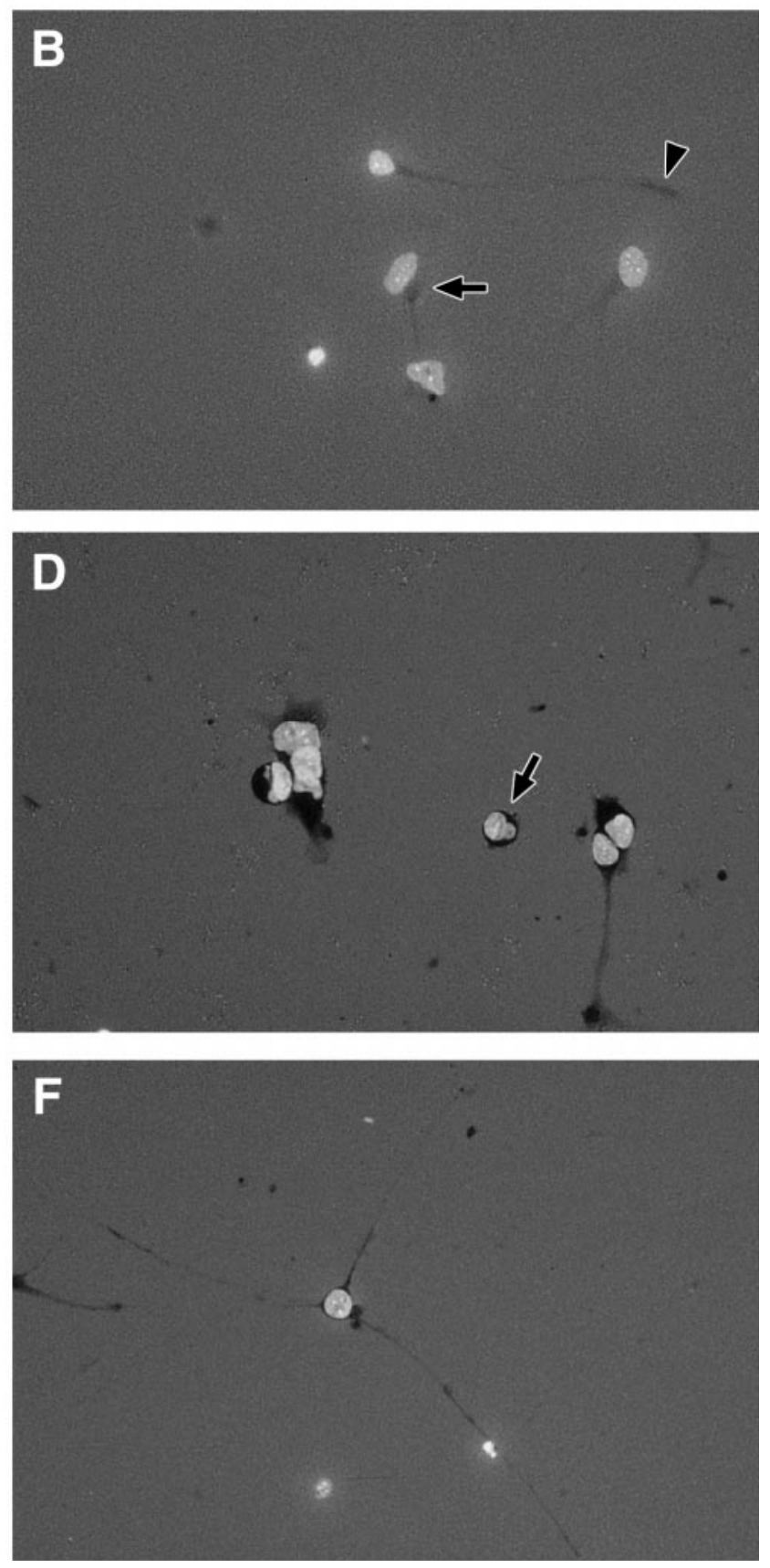

Figure 4. Immunocytochemistry shows increased expression of APP in motoneurons undergoing cell death in vitro. Motoneurons deprived of MEx (A, $C)$ generally showed stronger APP immunoreactivity compared with those cultured with MEx $(E)$. Aggregations of APP immunoreactivity were often observed in motoneurons in culture for $24 \mathrm{hr}$ without $\operatorname{MEx}(A)$ in the cell body (arrow) or in the distal tip of the neurite (arrowhead). By 36 hr without $\mathrm{MEx}$, many apoptotic motoneurons were observed in culture (arrow in $D$ ), and these cells were most often intensely APP-immunoreactive (arrow in $C$ ). $A, C, E$, APP immunoreactivity. $B, D, E$, The same field but with the UV filter to visualize the nuclei of the cells that were stained with the DNA-binding bis-benzimidazole dye Hoechst 33342. A, B, Motoneurons in culture for $24 \mathrm{hr}$ without MEx. $C, D$, Motoneurons in culture for $36 \mathrm{hr}$ without MEx. $E$, $F$, Motoneurons in culture for $36 \mathrm{hr}$ with MEx. All fields are shown at the same magnification (40× objective). Representative photomicrographs are shown. Three independent cultures were observed, with two coverslips/condition/time point/culture.

sites) or possible degradation products. This in vitro caspase-3 cleavage was inhibited by addition of DEVD-CHO to the reaction (Fig. 7).

\section{DISCUSSION}

Our research focuses on elucidating the underlying mechanisms modulating neuronal cell death during development. Given that administration of RNA and protein synthesis inhibitors delays several types of neuronal death (Martin et al., 1988; Oppenheim et al., 1990; Milligan et al., 1994), new gene expression may serve to mediate essential steps in this process. In the case of chick motoneurons, cells require $16-18 \mathrm{hr}$ to make the "decision" to die after withdrawal of trophic support (Milligan et al., 1994). If all 


\section{$\beta$-Amyloid Immunoreactivity}

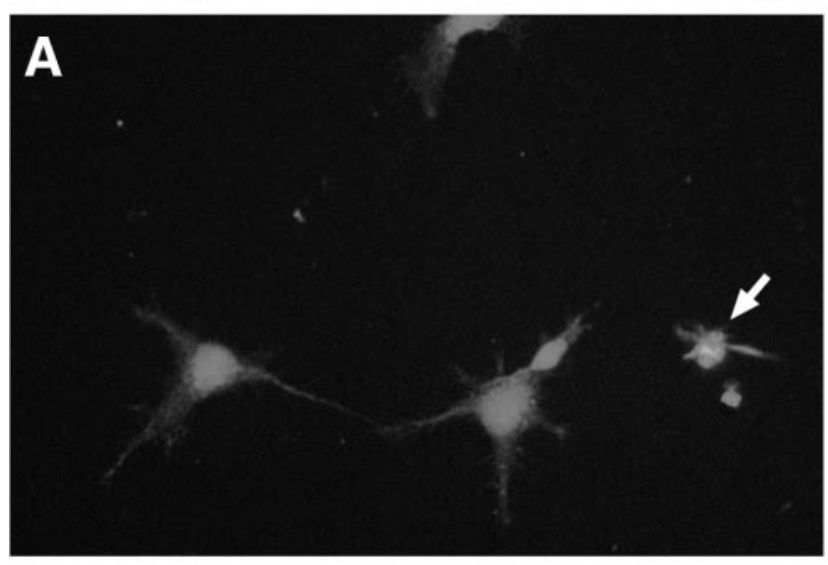

Hoechst Stain
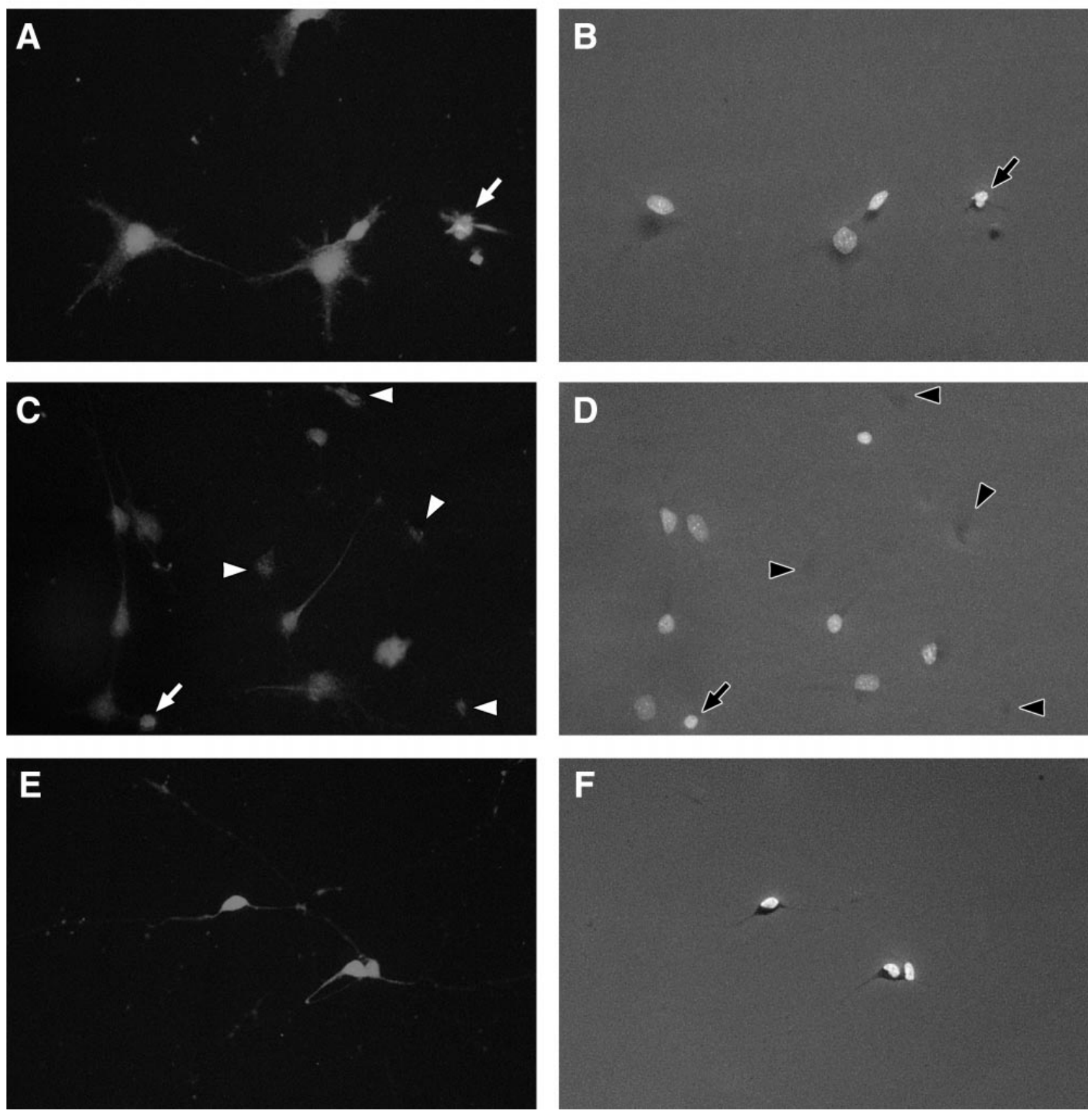

Figure 5. Immunocytochemistry shows increased expression of $\mathrm{A} \beta$ in motoneurons undergoing cell death in vitro. A $\beta$ immunoreactivity was similar within motoneurons deprived of $\operatorname{MEx}(A, C)$ and supplied with $\operatorname{MEx}(E)$. Apoptotic neurons were generally more immunopositive (arrows in $A-D)$. Aggregations of $\mathrm{A} \beta$ immunoreactivity were frequently observed in cultures deprived of MEx for $36 \mathrm{hr}(\operatorname{arrowheads}$ in $C, D$ ). These aggregations appeared to remain in the cellular debris (arrowheads in $C, D$ ). $A, C, E, \mathrm{~A} \beta$ immunoreactivity. $B, D, E$, The same field but with the UV filter to visualize the nuclei of the cells that were stained with the DNA-binding bis-benzimidazole dye Hoechst 33342 . $A, B$, Motoneurons in culture for 24 hr without MEx. $C, D$, Motoneurons in culture for $36 \mathrm{hr}$ without MEx. $E, F$, Motoneurons in culture for $36 \mathrm{hr}$ with MEx. Representative photomicrographs are shown. Three independent cultures were observed, with two coverslips/condition/time point/culture. Scale bars: $A, B, 10 \mu \mathrm{m} ; C-F, 35 \mu \mathrm{m}$.

the required components of the cell death machinery were already in place simply awaiting activation, then the time period between the death signal and commitment to death would presumably be much shorter, as seen for Fas-mediated death (Nagata and Golstein, 1995). In this study we have performed a molecular screen to identify messages that are differentially induced in developing motoneurons when deprived of adequate trophic sup- port and have identified APP as one of the upregulated messages in neuronal death.

APP seems to belong to a family of integral membrane proteins that have ubiquitous distribution in many cell types. Alternative splicing gives rise to three major APP isoforms, one 695 amino acids long and two others (751 and 770 amino acids) that contain an N-terminal Kunitz protease inhibitor domain. Although the 


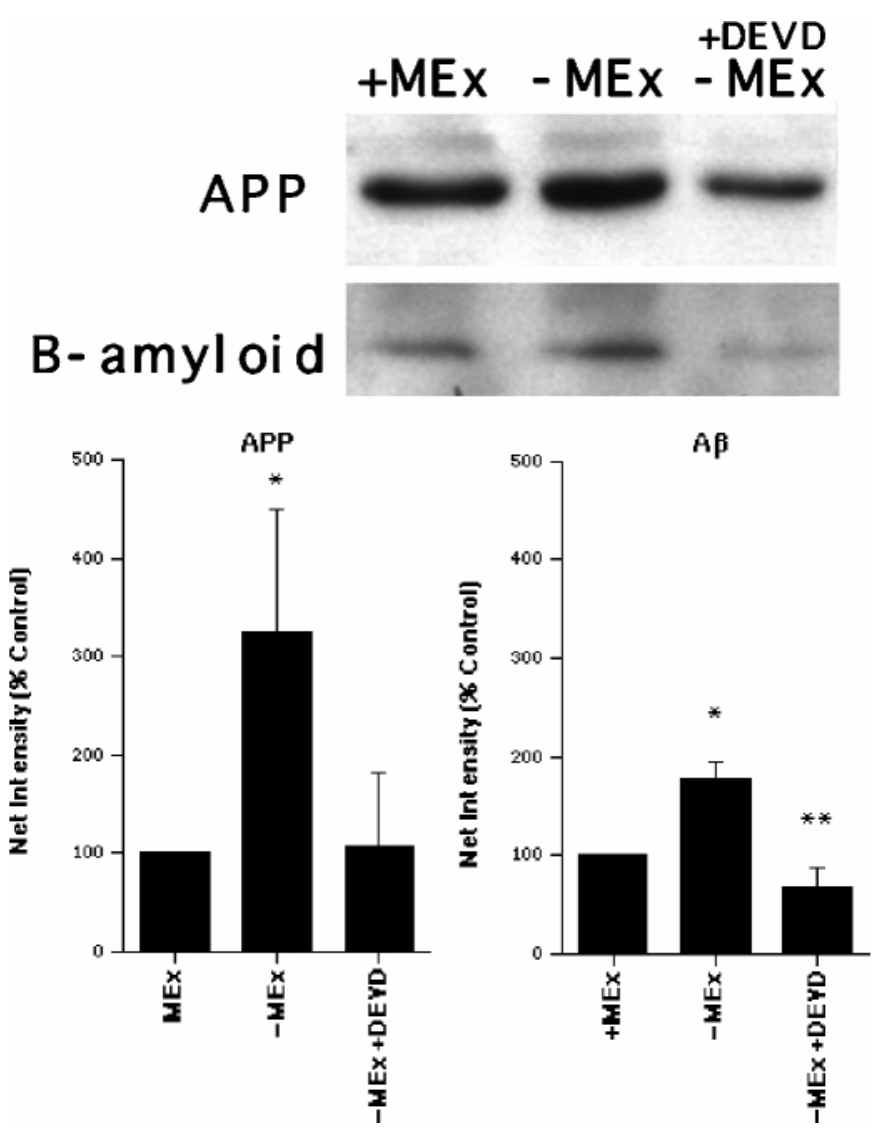

Figure 6. Western blot analysis indicates increased levels of APP and $\beta$-amyloid in cells deprived of MEx and decreased expression of APP and $\beta$-amyloid in dying cells when caspase- 3 is inhibited by the peptide DEVD-CHO. Protein extracts were collected from motoneurons cultured for $24 \mathrm{hr}$ either with $(+)$ or without ( - ) MEx or without MEx but treated with the peptide inhibitor of caspase-3 $(+D E V D)$. A, A $45 \mathrm{kDa}$ band was observed on the Western blot for APP (8\% PAGE gel). A $16 \mathrm{kDa}$ band was observed on the $\beta$-amyloid blot (15\% PAGE gel). Representative Western blots are shown. Four independent Western blots (individual experiment/blot) were performed for each antigen. The results were remarkably similar for each blot. $B$, Densitometry results of APP and $\beta$-amyloid Western blots are shown. Results are presented as percent control in which control represents motoneurons supplied with MEx (mean net intensity $\pm \mathrm{SEM} ; n=4$ blots each for APP or b-amyloid). * represents a statistically significant difference from control; $p \leq 0.05$. ** represents a statistically significant difference from control and from cells denied MEx; $p \leq 0.05$.

751 and 770 isoforms are found in both neuronal and nonneuronal tissues, the 695 isoform is predominantly found in neurons (Koo et al., 1990; Sisodia et al., 1993; Yamazaki et al., 1995). Proteolytic processing of APP that generates the A $\beta$ protein has been shown to be part of normal processing in the secretory pathways of neuronal and non-neuronal cells (Weidemann et al., 1989; Shoji et al., 1992; Busciglio et al., 1993; for extensive review, see Selkoe, 1994). Despite intense research on APP, little is known regarding its physiological function, although a recent report suggests that it may contribute to axonogenesis and arborization (Perez et al., 1997). Although it has been proposed that the physiological production of APP and subsequent generation of $\mathrm{A} \beta$ is a very early event in the development of Alzheimer's disease (AD) (for excellent review, see Selkoe, 1993; Yankner, 1996), recent reports suggest that the protein biology of this disease is very complex (De Strooper et al., 1998; Haass and Selkoe, 1998).

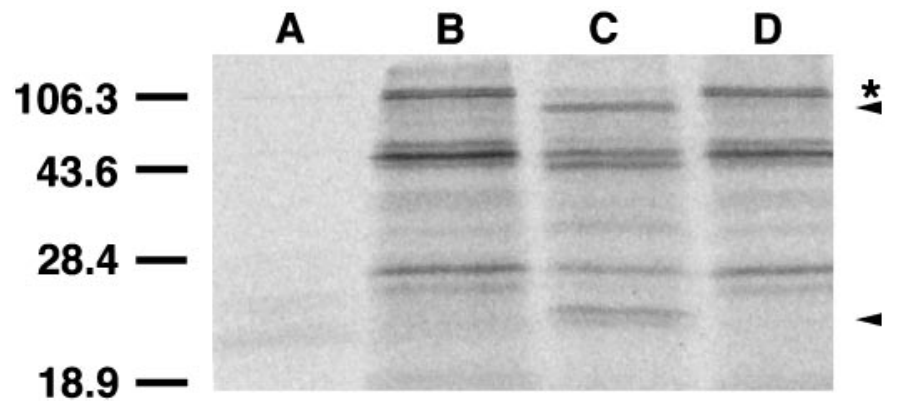

Figure 7. Purified recombinant caspase-3 cleaves APP. Lane B, A $5 \mu \mathrm{l}$ aliquot of in vitro translated ${ }^{35} \mathrm{~S}$-labeled $\mathrm{APP}_{695}$ is shown. Lane $C$, When the same amount of protein was incubated with $100 \mathrm{U}$ of purified human recombinant caspase- 3 (Biomol) at $37^{\circ} \mathrm{C}$ for $1 \mathrm{hr}$, cleavage products are observed. Lane $D$, Addition of $5 \mu \mathrm{M}$ DEVD-CHO to the reaction prevented the cleavage. Lane $A$, The in vitro translation reaction of vector (pBluescript KS) produced no labeled protein. The full-length APP is indicated by *. This size is similar to the size of the APP product produced when the cDNA clone is used to transfect P19 EC cells (Yoshikawa et al., 1992). The top arrow indicates the expected change in size of the full-length APP protein if caspase-3 cleaves at the APP N-terminal cleavage site. The bottom arrow indicates the appearance of the resulting small fragment presumably containing the $\mathrm{A} \beta$ protein after cleavage at both sites. Size markers are indicated in $\mathrm{kDa}$ units. Other bands may represent products from either alternate start codons or breakdown products.

At low concentrations, APP metabolic by-product $\mathrm{A} \beta$ has been shown to have a trophic effect, whereas at higher concentrations, it is toxic (Yankner et al., 1990). APP may function to stimulate cell proliferation (Saitoh et al., 1989), promote cell adhesion (Schubert et al., 1989), and promote neurite outgrowth (Milward et al., 1992). There is also sporadic evidence in the literature that neurons undergoing cell death may generate excess extracellular $\mathrm{A} \beta$ (LeBlanc, 1995). This excess $\mathrm{A} \beta$ may serve as a deathinducing signal to surrounding viable neurons. The toxic effect of $\mathrm{A} \beta$ when it is presented to neurons may occur by increased expression of immediate early genes (Anderson et al., 1995), nitric oxide production and NMDA receptor activation (Le et al., 1995), and/or downregulation of Bcl-2 and upregulation of BAX (Paradis et al., 1996). In fact, it has been recently demonstrated that when $\mathrm{A} \beta$ is administered extracellularly to neurons in culture, these cells are induced to die by a mechanism that involves caspase activation (Bozyczko-Coyne et al., 1997; Suzuki, 1997). Our results, on the other hand, suggest an intracellular, potentially toxic generation of an $\mathrm{A} \beta$-like molecule in dying neurons.

The message for APP was identified in our initial screen to identify genes that are differentially expressed in dying neurons. Is the increased expression of APP a specific result of the death program of the cell? Considering the results of our in situ hybridization study for APP in the developing spinal cord, this seems unlikely. The message for APP in the developing spinal cord does have a temporal distribution, with its greatest expression within motoneurons during the period of naturally occurring death. However, APP expression is not confined to motoneurons. Furthermore, APP expression is also prominent in developing muscle, suggesting a potential developmental role for this molecule in the interaction between motoneuron and target. Interestingly, a recent review indicates that soluble $\mathrm{A} \beta$ is capable of inhibiting acetylcholine release (Auld et al., 1998). It has been shown that neuromuscular blocking agents can rescue motoneurons from PCD (Pittman and Oppenheim, 1978). Therefore, low levels of soluble $\mathrm{A} \beta$ during development may serve to inhibit release of 
acetylcholine from motoneurons, thereby promoting their survival. In fact, it has recently been shown that soluble $A \beta$ is rapidly cleared from the CNS with little detrimental effect, whereas the fibrillar form is stable for a month and promotes both neuronal degeneration and gliosis (Weldon et al., 1998). These hypotheses warrant further investigation.

Although increased expression of APP may not necessarily be correlated with cell death, it may be a part of normal development and/or the stress response of neurons. Accordingly, increases in expression of APP have been observed in facial motoneurons of adult rats after axotomy (Sola et al., 1993). Because most of these motoneurons do not undergo cell death, the increased expression of APP alone does not necessarily precipitate death. The increased expression of APP observed in vitro in motoneurons deprived of trophic support and in motoneurons in vivo as they interact with their target suggests that increased expression of APP may be an initial response of neurons to inadequate, or loss of, trophic support. This expression may simply be coincident with the subsequent activation of caspase- 3 in cells that are committed to death.

The increased expression of APP may be directly involved in causing neuronal death, as our results also demonstrate that APP is a substrate for caspase-3 (CPP-32), a cysteine protease involved in the cell death of motoneurons as well as the death of many other cell types. Furthermore, in cultured motoneurons deprived of trophic support, inhibition of caspase-3, although rescuing dying cells (Li et al., 1996, 1997; Li, Prevette, Oppenheim, and Milligan, unpublished observations), also blocks the production of $\beta$-amyloid, a potentially toxic proteolytic product of APP. We observed decreased expression of APP in motoneurons deprived of trophic support but treated with inhibitors of caspase-3. These results, together with the observed increased expression of APP and $\mathrm{A} \beta$ in untreated dying cultures, suggest a potential feedback mechanism in which cleavage of intact APP and generation of $A \beta$ promotes enhanced APP production. Several studies have reported the toxic effects of $\mathrm{A} \beta$ when it is presented extracellularly to neurons (Yankner et al., 1990; Behl et al., 1994; Le et al., 1995; Forloni et al., 1996). Alternatively, treatment with the caspase-3 inhibitor DEVD may indirectly prevent an upregulation of APP, thereby making less APP available for cleavage to A $\beta$. However, because the levels of $\mathrm{A} \beta$ in DEVD-treated cells are significantly lower than that in cells denied MEx and in healthy control cells, although DEVD may prevent the increased production of APP, it seems to also be preventing caspase-3 cleavage of constitutively expressed APP. On the other hand, the reduction of APP observed in DEVD-treated cells may indicate that activation of caspases in dying cells may signal increased production of APP. These hypotheses are focuses of future investigation. Because caspases are thought to be active intracellularly (although precise localization is still unclear), the results of our research indicate a potential intracellular mechanism for the production and toxicity of $\mathrm{A} \beta$. Aggregations of APP and $\mathrm{A} \beta$ are prominent within motoneurons deprived of trophic support during the time when these cells are dying and appear to remain as deposits after the death of the cell. This is in agreement with the finding that hippocampal neurons are capable of producing intracellular $\mathrm{A} \beta$ (Tienari et al., 1997). Other findings also suggest that intracellular processing of APP generates A $\beta$ containing derivatives. Specifically, when wild-type APP is overexpressed in postmitotic neurons in vitro or in hippocampal neurons in vivo, there is increased accumulation of intracellular APP and $\mathrm{A} \beta$ and subsequent neuronal degeneration (Yoshikawa et al., 1992; Nishimura et al., 1998).
Immunocytochemical analysis of APP localization in motoneurons in vitro indicates that the protein is concentrated within the cell body. Although ultrastructural analysis is necessary to identify specifically the intracellular localization of APP and A $\beta$ within dying neurons, this result is in agreement with findings that APP-transfected kidney 293 cells show accumulation of APP and $\mathrm{A} \beta$ in the endoplasmic reticulum (Wild-Bode et al., 1997). The predicted peptide sequence of APP contains two potential caspase- 3 sites that would yield an $\mathrm{A} \beta$-containing molecule in the dying neuron. Considering that purified caspase- 3 cleaves APP in vitro, this hypothesis deserves a closer look. Analysis of the predicted APP peptide sequence indicates that, with the exception of the membrane-spanning region, the molecule is very hydrophilic. If APP is proteolytically processed by caspase-3 during cell death, it would yield a cytoplasmic molecule that contains a very hydrophobic region. This insoluble fragment could then potentially become trapped within the cytoplasm and contribute to the destruction of the cell. This scenario seems reasonable considering that in cultures of motoneurons deprived of trophic support, APP- or $\mathrm{A} \beta$-immunoreactive material was contained in cellular debris or even deposited on the culture dish after the cell remains had disintegrated. Such intracellular mechanisms may contribute to the pathology associated with Alzheimer's disease as other AD-associated molecules, the presenilins, have also been associated with apoptosis (Wolozin et al., 1996) and may also serve as substrates for caspase-type proteases (Loetscher et al., 1997; Suzuki, 1997).

The observation that APP is increased in dying motoneurons deprived of trophic support suggests that APP may serve as a substrate for the cell death protease caspase-3, thereby generating a potentially toxic intracellular $\mathrm{A} \beta$ during a normal developmental process, a sequence of events that could be reactivated in neuropathologies. In vitro experiments confirm that caspase-3 cleaves APP. Therefore developmental models may be useful for revealing the underlying molecular and biochemical mechanisms of still poorly understood neurodegenerative disorders.

\section{REFERENCES}

Anderson AJ, Pike CJ, Cotman CW (1995) Differential induction of immediate early gene proteins in cultured neurons by $\beta$-amyloid ( $\mathrm{A} \beta$ : association of $c$-Jun with $\mathrm{A} \beta$-induced apoptosis. J Neurochem 65:1487-1498.

Auld DS, Kar S, Quirion R (1998) $\beta$-Amyloid peptides as direct cholinergic neuromodulators: a missing link? Trends Neurosci 21:43-49.

Ausubel FM, Brent R, Kingston RE, Moore DD, Seidman JG, Smith JA, Struhl K (1996) Current protocols in molecular biology, p 10.1.4. New York: Wiley.

Behl C, Davis JB, Klier FG, Schubert D (1994) Amyloid $\beta$ peptide induces necrosis rather than apoptosis. Brain Res 645:253-264.

Boise LH, Gonzalez-Garcia M, Postema CE, Ding D, Lindstein T, Turka LA, Mao X, Nunez G, Thompson CB (1993) bcl-x and bcl-2-related gene that functions as a dominant regulation of apoptotic cell death. Cell 79:597-608.

Bozyczko-Coyne D, McKenna BA, Siman R (1997) Caspase mediation of $\mathrm{A} \beta$ neurotoxicity in vitro. Soc Neurosci Abstr 23:1628.

Bradford MM (1977) A rapid and sensitive method for the quantification of microgram quantities of protein utilizing the principle of protein-dye binding. Anal Biochem 72:248-254.

Buckbinder L, Brown DD (1992) Thyroid hormone-induced gene expression changes in the developing frog limb. J Biol Chem 267:25786-25791.

Busciglio J, Gabuzda DH, Matsudaira P, Yanker BA (1993) Generation of $\beta$-amyloid in the secretory pathway in neuronal and nonneuronal cells. Proc Natl Acad Sci USA 90:2092-2096.

Chu-Wang I, Oppenheim RW (1978a) Cell death of motoneurons in the chick embryo spinal cord. I. A light and electron microscopic study of 
naturally occurring and induced cell loss during development. J Comp Neurol 177:33-58.

Chu-Wang I, Oppenheim RW (1978b) Cell death of motoneurons in the chick embryo spinal cord. II. A quantitative and qualitative analysis of degeneration in the ventral root, including evidence for axon outgrowth and limb innervation prior to cell death. J Comp Neurol 177:59-86.

Clarke PGH, Oppenheim RW (1995) Neuron death in vertebrate development: in vivo models. In: Methods in cell biology, Vol 46 (Schwartz LM, Osborne BA, eds), pp 277-321. San Diego: Academic.

De Strooper B, Saftig P, Gaessaerts K, Vanderstichele H, Guhde G, Annaert W, Von Figura K, Van Leuven F (1998) Deficiency of presenilin-1 inhibits the normal cleavage of amyloid precursor protein. Nature 391:387-390.

Estus S, Zaks WJ, Freeman RS, Gruda M, Bravo R, Johnson Jr EM (1994) Altered gene expression in neurons during programmed cell death: identification of c-jun as necessary for neuronal apoptosis. J Cell Biol 127:1717-1727.

Forloni G, Bugiani O, Tagliavini F, Salmona M (1996) Apoptosismediated neurotoxicity induced by $\beta$-amyloid and PRP fragments. Mol Chem Neuropathol 28:163-171.

Freeman RS, Estus S, Johnson Jr EM (1994) Analysis of cell cyclerelated gene expression in postmitotic neurons: selective induction of cyclin D1 during programmed cell death. Neuron 12:343-355.

Garcia I, Martinou I, Tsujimoto Y, Martinou JC (1992) Prevention of programmed cell death of sympathetic neurons by the bcl-2 protoncogene. Science 258:302-304.

Greenlund LJS, Korsmeyer SJ, Johnson Jr EM (1995) Role of Bcl-2 in the survival and function of developing and mature sympathetic neurons. Neuron 15:649-661.

Haass C, Selkoe DJ (1998) A technical KO of amyloid- $\beta$ peptide. Nature 391:339-340.

Ham J, Babij C, Whitfield J, Pfarr CM, Lallemand D, Yaniv M, Rubin LL (1995) A c-Jun dominant negative mutant protects sympathetic neurons against programmed cell death. Neuron 14:927-939.

Hamburger V (1958) Regression versus peripheral control of differentiation in motor hypoplasia. Am J Anat 102:365-410.

Hamburger V (1975) Cell death in the development of the lateral motor column of the chick embryo. J Comp Neurol 160:535-546.

Hamburger V, Oppenheim RW (1982) Naturally occurring neuronal death in vertebrates. Neurosci Comment 1:39-55.

Koo EH, Sisodia SS, Cork LC, Unterbeck A, Bayney RM, Price DL (1990) Differential expression of amyloid precursor protein mRNAs in cases of Alzheimer's disease and in aged nonhuman primates. Neuron 4:97-104.

Le W-D, Colom LV, Xie W-J, Smith RG, Alexianu M, Appel SH (1995) Cell death induced by $\beta$-amyloid 1-40 in MES 23.5 hybrid clone: the role of nitric oxide and NMDA-gated channel activation leading to apoptosis. Brain Res 686:49-60.

LeBlanc A (1995) Increased production of $4 \mathrm{kDa}$ amyloid $\beta$ peptide in serum-deprived human primary neuron cultures: possible involvement of apoptosis. J Neurosci 15:7837-7846.

Li L, Oppenheim RW, Milligan CE (1996) Examination of the role of ICE family of cysteine proteases and their putative substrates in motoneuron cell death. Soc Neurosci Abstr 22:566.

Li L, Prevette D, Milligan CE, Oppenheim RW (1997) Motoneuron cell death following target deletion is not prevented by the inhibition of ICE family cysteine proteases. Soc Neurosci Abstr 23:1157.

Loetscher H, Deuschle U, Brockhaus M, Reinhardt D, Nelboeck P, Mous J, Grunberg J, Haass C, Jacobsen H (1997) Presenilins are processed by caspase-type proteases. J Biol Chem 272:20655-20659.

Martin DP, Schmidt RE, Distefano PS, Lowry OH, Clarke JG, Johnson Jr EM (1988) Inhibitors of protein synthesis and RNA synthesis prevent neuronal death caused by nerve growth factor deprivation. J Cell Biol 106:829-844.

Mesner PW, Epting CL, Hegarty JL, Green SH (1995) A timetable of events during programmed cell death induced by trophic factor withdrawal from neuronal PC12 cells. J Neurosci 15:7357-7366.

Milligan CE, Oppenheim RW, Schwartz LM (1994) Motoneurons deprived of trophic support in vitro require new gene expression to undergo programmed cell death. J Neurobiol 25:1005-1016.

Milligan CE, Prevette D, Yaginuma H, Homma S, Cardwell C, Fritz LC, Tomaselli KJ, Oppenheim RW, Schwartz LM (1995) Peptide inhibitors of the ICE protease family arrest programmed cell death of motoneurons in vitro and in vivo. Neuron 15:1-10.

Milward EA, Papadopoulos R, Fuller SJ, Moir RD, Small D, Beyreuther
K, Masters CL (1992) The amyloid protein precursor of Alzheimer's disease is a mediator of the effects of nerve growth factor on neurite outgrowth. Neuron 9:129-137.

Nagata S, Golstein P (1995) The Fas death factor. Science 267:1449-1456.

Nishimura I, Uetsuki T, Dani SU, Ohsawa Y, Saito I, Okamura H, Uchiyama Y, Yoshikawa K (1998) Degeneration in vivo of rat hippocampal neurons by wild-type Alzheimer amyloid precursor protein overexpressed by adenovirus-mediated gene transfer. J Neurosci 18:2387-2398.

Oppenheim RW (1991) Cell death during the development of the nervous system. Annu Rev Neurosci 14:453-501.

Oppenheim RW, Chu-Wang I, Maderdrot JL (1978) Cell death of motoneurons in the chick embryo spinal cord. III. The differentiation of motoneurons prior to their induced degeneration following limb-bud removal. J Comp Neurol 177:87-112.

Oppenheim RW, Haverkamp LJ, Prevette D, McManaman JL, Appel SH (1988) Reduction of naturally occurring motoneuron death in vivo by a target derived neurotrophic factor. Science 240:919-922.

Oppenheim RW, Prevette D, Tytell M, Homma S (1990) Naturally occurring and induced neuronal death in the chick embryo in vivo requires protein and RNA synthesis: evidence for the role of cell death genes. Dev Biol 138:104-113.

Oppenheim RW, Houenou LJ, Johnson JE, Lin LF, Li L, Lo AC, Newsome AL, Prevette DM, Wang S (1995) Developing motor neurons rescued from programmed and axotomy-induced cell death by GDNF. Nature 373:344-346.

Paradis E, Douillard H, Koutroumanis M, Goodyer C, LeBlanc A (1996) Amyloid $\beta$ peptide of Alzheimer's disease downregulates Bcl-2 and upregulates Bax expression in human neurons. J Neurosci 16:7533-7539.

Perez RG, Zheng H, Van der Ploeg LHT, Koo EH (1997) The $\beta$-amyloid precursor protein of Alzheimer's disease enhances neuron viability and modulates neuronal polarity. J Neurosci 17:9407-9414.

Pittman RH, Oppenheim RW (1978) Neuromuscular blockade increases motoneuron survival during normal cell death in the chick embryo. Nature 271:364-366.

Saitoh T, Sundsmo M, Roch JM, Kimura N, Cole G, Schubert D, Oltersdorf T, Schenk DB (1989) Secreted form of amyloid beta protein precursor is involved in the growth regulation of fibroblasts. Cell 58:615-622.

Schubert D, Jin LW, Saitoh T, Cole G (1989) The regulation of amyloid beta protein precursor secretion and its modulatory role in cell adhesion. Neuron 3:689-694.

Schwartz LM, Milligan CE (1996) Cold thoughts of death: the role of ICE proteases in neuronal cell death. Trends Neurosci 19:555-562.

Schwartz LM, Kosz L, Kay BK (1990) Gene activation is required for developmentally programmed cell death. Proc Natl Acad Sci USA 87:6594-6598.

Schwartz LM, Milligan CE, Bielke W, Robinson SJ (1995) Cloning cell death genes. Methods Cell Biol 46:107-138.

Selkoe DJ (1993) Physiological production of the $\beta$-amyloid protein and the mechanism of Alzheimer's disease. Trends Neurosci 16:403-409.

Selkoe DJ (1994) Amyloid $\beta$-protein precursor: new clues to the genesis of Alzheimer's disease. Curr Opin Neurobiol 4:708-716.

Shoji M, Golde TE, Ghiso J, Cheun TT, Estus S, Shaffer LM, Cai X-D, McKay DM, Tintner R, Frangione B, Younkin SG (1992) Production of the Alzheimer amyloid $\beta$ protein by normal proteolytic processing. Science 258:126-129.

Sisodia SS, Koo EH, Hoffman PN, Perry G, Price DL (1993) Identification and transport of full-length amyloid precursor proteins in rat peripheral nervous system. J Neurosci 13:3136-3142.

Sola C, Garcia-Ladona FJ, Sarasa M, Mengod G, Probst A, Palacios G, Palacios JM (1993) $\beta$ APP gene expression is increased in the rat brain after motor neuron axotomy. Eur J Neurosci 5:795-808.

Suzuki A (1997) Amyloid beta-protein induces necrotic cell death mediated by ICE cascade in PC12 cells. Exp Cell Res 234:507-511.

Tienari PJ, Ida N, Ikonen E, Simons M, Weidemann A, Multhaup G, Masters CL, Dotti CG, Beyreuther K (1997) Intracellular and secreted Alzheimer $\beta$-amyloid species are generated by distinct mechanisms in cultured hippocampal neurons. Proc Natl Acad Sci USA 94:4125-4130.

Wang A, Brown DD (1991) A gene expression screen. Proc Natl Acad Sci USA 88:11505-11509.

Wang X, Pai J-T, Wiedenfeld EA, Medina JC, Slaughter CA, Goldstein JL, Brown MS (1995) Purification of an interleukin- $1 \beta$ converting 
enzyme-related cysteine protease that cleaves sterol regulatory element-binding proteins between the leucine zipper and transmembrane domains. J Biol Chem 270:18044-18050.

Weidemann A, Konig G, Bunke D, Fischer P, Salbaum JM, Masters CL, Beyreuther K (1989) Identification, biogenesis, and localization of precursors of Alzheimer's disease A4 amyloid protein. Cell 57:115-126.

Weldon DT, Rogers SD, Ghilardi JR, Finke MP, Cleary JP, O'Hare E, Esler WP, Maggio JE, Mantyh PW (1998) Fibrillar $\beta$-amyloid induces microglial phagocytosis, expression of inducible nitric oxide synthase, and loss of a select population of neurons in the rat CNS in vivo. J Neurosci 18:2161-2173.

Wild-Bode C, Yamazaki T, Capell A, Leimer U, Steiner H, Ihara Y, Haass C (1997) Intracellular generation and accumulation of amyloid $\beta$-peptide terminating at amino acid 42. J Biol Chem 272:16085-16088.

Wolozin B, Iwasaki K, Vito P, Ganjei JK, Lacana E, Sunderland T, Zhao B, Kusiak JW, Wasco W, D’Adamio L (1996) Participation of presenilin 2 in apoptosis: enhanced basal activity conferred by an Alzheimer mutation. Science 274:1710-1713.
Yamamoto Y, Livet J, Pollock RA, Garces A, Arce V, deLapeyriere O, Henderson CE (1997) Hepatocyte growth factor (HGF/SF) is a muscle-derived survival factor for a subpopulation of embryonic motoneurons. Development 124:2903-2913.

Yamazaki T, Selkoe DJ, Koo EH (1995) Trafficking of cell surface beta-amyloid precursor protein: retrograde and transcytotic transport in cultured neurons. J Cell Biol 129:431-442.

Yankner BA (1996) Mechanisms of neuronal degeneration in Alzheimer's disease. Neuron 16:921-932.

Yankner BA, Duffy LK, Kirschner DA (1990) Neurotrophic and neurotoxic effects of Amyloid $\beta$ protein: reversal by tachykinin neuropeptides. Science 250:279-282.

Yin X-M, Oltval ZN, Korsmeyer SJ (1994) BH1 and BH2 domains of bcl-2 are required for inhibition of apoptosis and heterodimerization with Bax. Nature 369:321-323.

Yoshikawa K, Aizawa T, Hayashi Y (1992) Degeneration in vitro of post-mitotic neurons overexpressing the Alzheimer amyloid protein precursor. Nature 359:64-67. 